\title{
A patient's diary: episode 20 - A trip to Barcelona
}

Hilda and I decided that I needed some distraction from my health problems and a change of air. So she has arranged for us to come on this holiday in Barcelona, a splendid historic city in the Catalan part of Spain, which we have not visited before. We did spend some time on the Costa del Sol with Sheila when she was little but that was a different kind of experience entirely and did not involve getting up quite so early. This trip was all organised by Hilda who chose to book us on a low-cost airline called Hot-Air. She booked both the flight and the hotel on our computer which I thought was a little reckless as it involved revealing our credit card number (and security code) to a firm about whom we know nothing, but Hilda says the flights only cost $£ 1$ each (plus $£ 75$ tax and baggage supplement) and everyone does it this way nowadays.

This morning we had to get up at 4 a.m. and go by taxi and bus to a very strange airport (I think it used to be a bomber base in World War Two) which is apparently the European headquarters of Hot-Air. We had to stand in an enormous queue at the checkin desk while young men and women attired in the red and white polka-dotted uniform of the company entertained us with songs and jokes and supposedly helpful tips about flying. I thought the whole thing lacked the dignity that one expects of an International Airline but Hilda said it made the wait less dreary. Boarding the aeroplane (a garishly red splattered Boeing 737) was even less dignified as there were no booked seats and some of the young people and children scrambled past us using disgraceful language in their haste to get near the windows. The stewardesses were admittedly friendly but I really don't like those red spotted tee shirts with the legend: 'Hot for You: Ready to Fly?' And I especially don't think the captain should have worn one but, there you go, that's what young people like these days. At least they conducted the safety briefing with some attempt at seriousness. Unfortunately our fellow passengers paid scant attention and indeed spent most of the journey calling across the aisle at each other with obscene descriptions of how they intended to spend their holiday.
At any rate, we arrived on time and had a swift, uneventful train ride to our hotel which is called the Katarina de Aragon. In the lobby there is a large picture of Henry the Eighth raising a pint glass of Guinness to his lips and winking broadly. I suppose this is intended to make English visitors feel at home. I must say our room was very nice with everything you could wish for including tea-making facilities of which we availed ourselves gratefully. Then it was time for a guided tour of the City on a nice, comfortable bus with stops off at all the key attractions. We saw the broad avenue of the Ramblas in all its glory and we looked round the Medieval Quarter or Barrio Gotico with its old cathedral and cloisters. It was quite warm but what with all the adrenalin flowing I felt really well with barely a twinge from my liver and other internal organs. We had lunch in an excellent cafeteria where all the dishes were illustrated in full colour on the large menus so there was no risk of ordering something unsuitable. We even chatted to another mature couple with whom we had things in common; both suffered with their health and had not had what I would call adequate care from their local practitioners. It made me feel that $\mathrm{Dr}$ Teacher and Co are really not too bad. I even began to miss them a little, especially $\mathrm{Dr}$ Brenda. I must remember to send her a postcard. Then we got back on the bus and our English Guide, Victoria, told us all about the new cathedral called the Sagrada Familia which they have been building since 1908 . She is very knowledgeable about art and architecture for one so young. And very patient with our questions about practical matters like the whereabouts of the toilets and whether it was safe to drink the water and the Spanish names of a few simple remedies we might need from the chemist. I was quite impressed that Hot-Air tours had managed to secure her services.

The Sagrada Familia was really inspiring, its many towers soaring majestically up into the blue sky above and making one quite giddy just to look at it. As I said to Hilda the patience it must have taken to go on building it all these years is a tribute to their Faith. Hilda liked all the mosaic animal decorations, but in her view, a smaller building would have been just as good and much less expensive. I'm afraid that she is unable to grasp the epic vision of an artist like Gaudi.

By this time we were somewhat exhausted and were glad to return to the Hotel Katarina for another cup of tea and a little nap. When I awoke, to my dismay, I found that my pancreas was in a state of agitation. Or was it my liver, to which I have given little thought in recent weeks, again showing its ugly side? I had a distinct feeling of nausea and a heaviness in the rectum, reminding me that it was now 3 days since my last satisfactory bowel movement. I immediately roused Hilda and apprised her of the situation. I said that we needed to obtain some urgent medical advice before things deteriorated even further. I reminded her that we were on foreign soil and that accessing the Spanish Health Service (if indeed they had one) might be difficult. Hilda very intelligently suggested phoning reception and asking for Victoria who had told us she would be available in an emergency which this clearly was.

Fortunately she was already in the hotel and came up to our room within a few minutes. Victoria quickly understood the urgency of the situation and as usual knew what to do. 'I shall take you to a friend of mine,' she said, 'a very good doctor called Rosario Perez. Her office is in a little square, not very far from here. I'll call her on my mobile and see if she can fit you in. No problem.' She got us a taxi and in no time at all we had rolled down the Ramblas and into the little square in question. Dr Perez's surgery was on the 5th floor and fortunately there was a lift because by this time I was feeling too shaky to manage the stairs. I wondered whether there might have been something in the paella I had for lunch that had caused an abnormal reaction in one of my digestive enzymes and I wondered if Victoria would be able to put that into Spanish so that the doctor would appreciate that I was not without some medical knowledge myself. When we reached the fifth floor there was a very pleasant waiting room, much more stylish than anything you would see in an English GP surgery. The whole ambience was very calming. I was wondering how long we would have to wait 
when suddenly $\mathrm{Dr}$ Rosario came into the room. She was a delightful, jolly woman with a reassuring smile; and she spoke excellent English with a slight but charming accent. She ushered Hilda and me into her consulting room and offered us a seat on comfortable armchairs. All this luxury was making me a little uneasy about how much this was going to cost us. But we were carrying Hot-Air Comprehensive travel insurance, a precaution on which I insisted, not wanting to be mired in EU bureaucracy and form-filling etcetera, although we do have those little plastic cards. Dr Rosario listened carefully to my symptoms and gave me a thorough examination. Her calming presence reminded me a little of Dr Brenda and the inflammation of my pancreas (or liver) was already beginning to subside under her gentle touch. I mentioned that I had been constipated (or constipado) as I put it, trying to meet her halfway in the matter of language. I am told that foreigners always appreciate it if you have a try. Dr Rosario looked rather puzzled and suggested some nose drops, until Victoria explained that 'constipado' in Spanish means 'a cold'. I decided to conduct the rest of the consultation in English.

When I was dressed again, Dr Rosario sat at her desk and wrote out a large number of prescriptions, one item on each sheet. They are obviously much more generous when it comes to prescribing than their English counterparts who seem to grudge you every spoonful of cough linctus as though it was vintage champagne. We said a cordial goodbye to the doctor while Victoria attended to the paperwork with her secretary. She said she would add the bill to our Hot-Air Account so that we could easily claim it back on the insurance. Then we went to the nearest Farmacia for my prescriptions. I was glad to see that they included a mild laxative, an antispasmodic, an enzyme preparation to aid the digestion, some excellent vitamin supplements and a week's supply of Spanish Amoxicillin. As we took our seats in the Katarina's Tapas bar and ordered our Sangria I felt I could look forward to trouble-free health for the rest of the weekend. Hilda was not so certain, but she does worry about me a good deal and I think the relaxation will do her good.

We are grateful to John Salinsky for these extracts from Norman Gland's diary.

DOI: 10.3399/bjgp08X319837

\section{Professor Jan Van Es}

Jan Van Es died on 28 June 2008 at the age of 86 . In 1966 he was the first GP in the Netherlands to be appointed to a university professorship. He held a newly created chair in the University of Utrecht, at first combining this with his practice at Apeldoorn and later, with editing a medical journal.

I first met him in 1972 at Leeuwenhorst, near Haarlem, at a conference centre in the middle of the Dutch bulbfields, in full bloom. The conference proved to be important because it led immediately to the formation of the Leeuwenhorst European Study Group. Representatives from 11 European countries (from both sides of the 'iron curtain') agreed on a European definition of the role of the GP in healthcare. This became widely accepted as a basis for creating specific early postgraduate training programmes for future practitioners.

Jan followed Patrick Byrne as chairman of this group and I was secretary to them both. The group continued to meet twice yearly for the next 7 years in different member countries before handing over its important role to a younger group representing 21 countries.

For me, Jan was an especially close friend over 36 years. We talked by telephone every week during the 2 years of his final illness.

He had the gift of always making other people feel valued. I have known very few other colleagues who have been such good listeners or so good at drawing out contributions from a large audience in a lecture theatre.

Jan chose to be an associate of our College in 1963. In 1967, the College presented him with its honorary fellowship. The Dutch government honoured him with a knighthood in 1982. I cannot believe that he is no longer there to talk to.

\section{John Horder}

DOI: 10.3399/bjgp08X319846

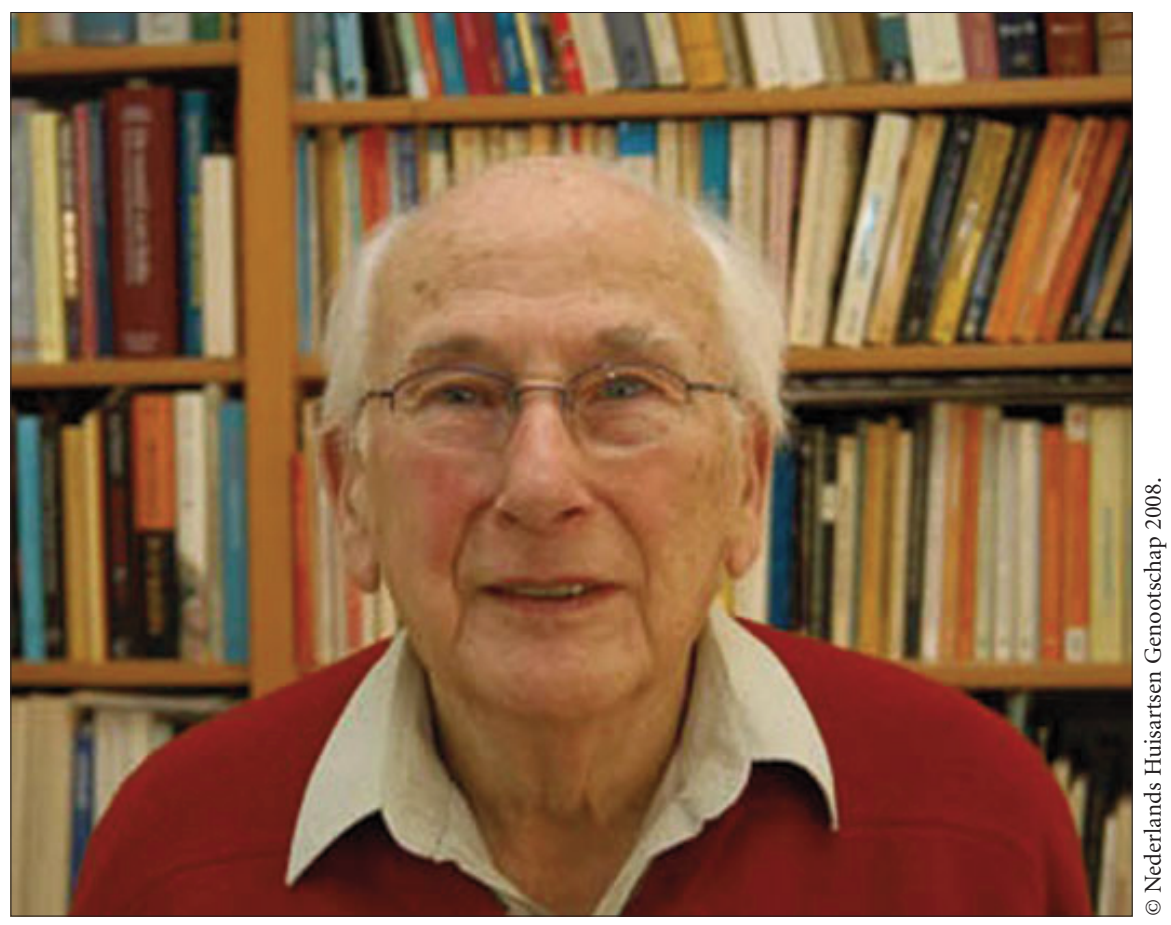

